\title{
Ĕ̆itim Fakültesi Öğretim Elemanlarının Psikolojik Güçlendirilmelerinin Örgütsel Sessizlik Davranışları Üzerindeki Etkisi
}

\author{
Orhan Kahya ${ }^{1}$, Aycan Çiçek-Sağlam ${ }^{1}$ \\ ${ }^{1}$ Eğitim Bilimleri Bölümü, Eğitim Fakültesi, Muğla Sıtkı Koçman Üniversitesi, Muğla, Türkiye
}

Sorumlu Yazar: Orhan Kahya, okahya1@gmail.com

Makale Türü: Araştırma Makalesi

Kaynak Gösterimi: Kayha, O., \& Çiçek-Sağlam, A. (2019). Eğitim fakültesi öğretim elemanlarının psikolojik güçlendirilmelerinin örgütsel sessizlik davranışları üzerindeki etkisi. Eğitimde Kuram ve Uygulama, 15(2), 171-185. doi: 10.17244/eku.467026

The Effect of Psychological Empowerment on Organizational Silence Behaviors of Education Faculty Lecturers

Orhan Kahya ${ }^{1}$, Aycan Çiçek-Sağlam ${ }^{1}$

${ }^{1}$ Department of Educational Sciences, Faculty of Education, Muğla Sitkı Koçman University, Muğla, Turkey

Corresponding Author: Orhan Kahya, okahya1 @gmail.com

Article Type: Research Article

To Cite This Article: Kayha, O., \& Çiçek-Sağlam, A. (2019). Eğitim fakültesi öğretim elemanlarının psikolojik güçlendirilmelerinin örgütsel sessizlik davranışları üzerindeki etkisi. Eğitimde Kuram ve Uygulama, 15(2), 171-185. doi: 10.17244/eku.467026 


\title{
Eğitim Fakültesi Öğretim Elemanlarının Psikolojik Güçlendirilmelerinin Örgütsel Sessizlik Davranışları Üzerindeki Etkisi
}

\author{
Orhan Kahya ${ }^{1}$, Aycan Çiçek-Sağlam ${ }^{1}$ \\ ${ }^{1}$ Eğitim Bilimleri Bölümü, Eğitim Fakültesi, Muğla Sıtkı Koçman Üniversitesi, Muğla, Türkiye \\ ORCID: http://orcid.org/0000-0001-7932-2982 \\ ORCID: http://orcid.org/0000-0003-2598-4117
}

\begin{tabular}{|c|c|}
\hline$\ddot{O} z$ & Makale Bilgisi \\
\hline $\begin{array}{l}\text { Bu araştırmada, eğitim fakültelerinde çalışan öğretim elemanlarının psikolojik } \\
\text { güçlendirilmelerinin örgütsel sessizlik davranışları üzerindeki etkisini ortaya koymak } \\
\text { amaçlanmıştır. Araştırma tarama modelinde desenlenmiştir. Araştırmanın çalışma evrenini, 2017- } \\
2018 \text { eğitim öğretim yılında Muğla Sıtkı Koçman Üniversitesi, Adnan Menderes Üniversitesi ve } \\
\text { Pamukkale Üniversitesi Eğitim Fakültelerinde görev yapan öğretim elemanları oluşturmaktadır. } \\
\text { Araştırmanın örneklemini, oransız küme örnekleme tekniğine göre seçilen } 147 \text { öğretim elemanı } \\
\text { oluşturmaktadır. Araştırmada veri toplama aracı olarak Psikolojik Güçlendirme Ölçeği ve } \\
\text { Örgütsel Sessizlik Ölçeği kullanılmıştır. Psikolojik güçlendirme ölçeğinden alınan puanların } \\
\text { yükselmesi hem ölçeğin boyutlarında hem de toplam puanda öğretim elemanlarının örgüt } \\
\text { tarafından psikolojik olarak olumlu yönde güçlendirildiğini göstermektedir. Örgütsel sessizlik } \\
\text { ölçeğinden her bir faktörden alınan yüksek puan, örgütsel sessizliğin arttığına işaret etmektedir. } \\
\text { Verilerin çözümlenmesinde betimsel istatistikler, t-testi, ANOVA ve çoklu regresyon analizi } \\
\text { kullanılmıştır. Araştırma sonuçlarına göre, eğitim fakültesi öğretim elemanlarının psikolojik } \\
\text { güçlendirilmeleri orta düzeyin üzerindedir. Öğretim elemanları, örgütsel sessizliğin } \\
\text { boyutlarından kabullenici sessizlikte en düşük puanı almışlardır. Bunu savunma amaçlı sessizlik } \\
\text { takip ederken, kurum yararına sessizlik alt boyutunda en yüksek puanı almışlardır. Psikolojik } \\
\text { güçlendirme kabullenici sessizliğin \%22'sini açıklamaktadır. Psikolojik güçlendirmenin } \\
\text { anlamlılık ve etki alt boyutları kabullenici sessizliğin negatif yönde anlamlı yordayıcılarıdır. } \\
\text { Psikolojik güçlendirme savunma amaçlı sessizliğin \%16'sını açıklamaktadır. Psikolojik } \\
\text { güçlendirmenin sadece özerklik alt boyutu savunma amaçlı sessizliğin negatif yönde anlamlı } \\
\text { yordayıcısıdır. Son olarak psikolojik güçlendirme kurum yararına sessizliğin \% \%'sini } \\
\text { açıklamaktadır. Psikolojik güçlendirmenin yeterlilik boyutu kurum yararına sessizliğin pozitif } \\
\text { yönde anlamlı yordayıcısıdır. }\end{array}$ & $\begin{array}{l}\text { Anahtar Kelimeler: } \\
\text { Örgütsel sessizlik, } \\
\text { Psikolojik güçlendirme, } \\
\text { Sessizlik davranışları }\end{array}$ \\
\hline
\end{tabular}




\section{The Effect of Psychological Empowerment on Organizational Silence Behaviors of Education Faculty Lecturers}

\begin{tabular}{ll}
\hline Abstract & Article Info \\
\hline The purpose of this study is to determine the effect of psychological empowerment on \\
organizational silence behaviors of education faculty lecturers. The sample of this Keywords: Organisational \\
descriptive study consists of 147 academicians working in education faculties at Mugla silence, Psychological \\
Sitki Kocman University, Adnan Menderes University and Pamukkale University. The data empowerment, Silence \\
of the study were collected through the administration of the psychological empowerment behaviours \\
and organizational silence behavior scales in relation to the lecturers in the sample. Higher \\
scores in psychological empowerment mean that lecturers in an education faculty are Article History: \\
empowered in a positive way, while higher scores in the organizational silence behavior Received: 03 October 2018 \\
scale mean that education faculty lecturers are more silent. In the analysis of the data, Revised: 04 December 2019 \\
descriptive statistics, $t$ test, ANOVA and multiple regression analysis were conducted. Accepted: 20 December 2019 \\
Findings of the study show that lecturers in education faculties are psychologically \\
empowered above the medium level, and they show at least acquiescent silence. Article Type: Research \\
Psychological empowerment explains $22 \%$ of acquiescent silence, $16 \%$ of defensive silence Article \\
and $7 \%$ of prosocial silence behaviors of lecturers in education faculties.
\end{tabular}




\section{Giriş}

Günümüzde yükseköğretim kurumlarının, özel olarak da eğitim fakültelerinin performansını arttırması gerektiği konusunda yoğun bir baskının olduğu bilinmektedir. Eğitim fakültelerinde performansı arttırmak ve nitelikli çıktılar elde etmek büyük ölçüde öğretim elemanlarına bağlıdır. Çünkü bir örgütün performansının ve üretkenliğinin yüksek olmasında, oradaki çalışanlar son derece önemlidir (Jomah, 2017). Psikolojik güçlendirme (Spreitzer, 1995) ve sessizlik örgütteki değişim ve performans artışı için önemli örgütsel davranış boyutlarındandır. Psikolojik güçlendirme, çalışanların kişisel kontrol algısını ve motivasyonunu yükselterek pozitif örgütsel ve yönetsel çıtıların elde edilmesini sağlar (Quinn \& Spreitzer, 1997). Örgütsel sessizlik ise örgütün performansını yükseltebilecek ya da daha kötüye düşürebilecek bir davranış seçimidir (Bagheri, Zarei \& Aeen, 2012). Bu anlamda her iki kavramın da önemli örgütsel davranış boyutlarından olduğu söylenebilir.

İlk olarak Conger ve Kanungo (1988) tarafından ortaya atılan psikolojik güçlendirme, Bandura'nın (1982) özyeterlik çalışmalarıyla ilişkilendirilmiş bir kavramdır. Buna göre psikolojik güçlendirme çalışanların güçlendirilmeye ilişkin algılarına ve bilişsel durumlarına odaklanmaktadır. Conger ve Kanungo (1988) ve Thomas ve Velthouse'un (1990) çalışmalarından yola çıkan Spreitzer (1995) anlamlılık, yeterlilik, özerklik ve etki olmak üzere dört boyuttan oluşan bir ölçme aracı geliştirmiştir. Bu dört boyutun birlikte, çalışanların iş yerindeki rollerinde etkili olduğu söylenebilir.

Buna göre anlamlılık, örgütte bir işin yapılış amacının bireyler için taşıdığı değer ve önem olarak tanımlanabilir. Yeterlilik, bireyin işini yapma konusunda kendisine ve yeteneklerine güvenmesi ile ilgilidir. Özerklik, bireyin işini nasıl yapacağı konusunda karar verme özgürlüğü ve işi konusunda inisiyatif kullanabilmesi olarak tanımlanmaktadır. Son olarak etki ise bireylerin örgütsel sonuçlar üzerinde herhangi bir etkilerinin olup olmadığını hissetmeleri ile ilgilidir.

Tablo 1. Psikolojik güçlendirme ile birlikte çalışılan bazı örgütsel davranış kavramları

\begin{tabular}{|c|c|}
\hline Araştırma bilgisi & $\begin{array}{l}\text { Psikolojik güçlendirme ile birlikte ele alınan } \\
\text { değişken }\end{array}$ \\
\hline $\begin{array}{l}\text { (Safari, Haghighi, Rastegar \& Jamshidi, 2011), (Toplu } \\
\& \text { Akça, 2013) }\end{array}$ & Örgütsel öğrenme \\
\hline $\begin{array}{l}\text { (Altınkurt, Türkkaş-Anasız \& Ekinci, 2016) } \\
\text { (Akgündüz, Kale \& Pazarbaş1, 2014) (Çavuşoğlu \& } \\
\text { Güler, 2017) }\end{array}$ & Örgütsel vatandaşlık \\
\hline $\begin{array}{l}\text { (Tolay \& diğerleri, 2012)(Jordan \& diğerleri, } \\
\text { 2017)(Wang \& Lee, 2009)(Eydoğmuş \& diğerleri, } \\
\text { 2015) }\end{array}$ & İş doyumu \\
\hline (Othman \& Barakat, 2016)(İșcan \& Çakır, 2016) & Öz yeterlik \\
\hline (Avan, Zorlu, \& Baytok, 2016) & Örgütsel sessizlik \\
\hline (Karakaş \& Serçek, 2014)(Oktuğ, 2017) & Örgütsel bağlılık \\
\hline (Jordan \& diğerleri, 2017) & Örgütsel adanmışlık \\
\hline (Arslantaş, 2007) & Dönüşümcü liderlik \\
\hline (Çalışkan, 2011) & İletişim \\
\hline (Erdem, Gökmen, \& Türen, 2016) & İș performans1 \\
\hline (Taştan, 2014) & Psikolojik iyi oluş \\
\hline (Nartgün \& Demirer, 2017) & Örgütsel imaj \\
\hline (Bolat, Bolat \& Yüksel, 2016) & Hizmetkâr liderlik \\
\hline (Yürür \& Demir, 2011) & Örgütsel adalet \\
\hline (Fettahlıoğlu \& Sünbül, 2015) & Duygusal zekâ \\
\hline
\end{tabular}

Psikolojik güçlendirme konusunda eğitim alanında Türkiye'de yapılan çalışmaların (Gümüş, 2013; Odabaş, 2014; Şan, 2017) sınırlı sayıda olduğu bilinmektedir. Akademisyenlerle yapılan psikolojik güçlendirme çalışmaların da benzer şekilde sınırlı sayıda olduğu söylenebilir. Tolay, Sürgevil ve Topoyan'ın (2012) toplam 25 fakültede görev yapan 243 araştırma görevlisinden elde ettikleri bulgulara göre, psikolojik güçlendirme boyutlarından en yüksek ortalama puan yeterlilikten, en düşük ortalamaya puan ise etki alt boyutundan olduğu dikkat çekmektedir. Dolayısıyla araştırma görevlilerinin işlerini yapabilmeleri konusunda kendilerine güven duyduklarını ancak özellikle çalıştıkları bölümdeki sonuçlar üzerindeki etkilerinin düşük olduğunu hissettiklerini söylenebilir. Eydoğmuş, Ergeneli ve 
Camgoz'ün (2015) yaptığı çalışmada akademisyenlerin psikolojik güçlendirilme düzeyi yüksek bulunmuştur. Avusturya, Hırvatistan, Çekya, Almanya, Sırbistan ve Slovenya'daki üniversitelerde çalışan 409 öğretim elemanıyla yapılan bir diğer araştırma gösteriyor ki, adı geçen ülkelerin tümünde akademisyenlerin psikolojik güçlendirilme düzeyi yüksektir (Jordan, Miglič, Todorović, \& Marič, 2017).

Bununla birlikte psikolojik güçlendirmenin çeşitli örgütsel davranış kavramları ile birlikte ele alındığı araştırmalar yürütülmüştür. Tablo 1'de son yıllarda psikolojik güçlendirme ile birlikte ele alınan bazı örgütsel davranış kavramlarının olduğu çalışmalar yer almaktadır.

Seibert, Wang ve Courtright'ın (2011) psikolojik güçlendirme konusundaki meta-analiz çalışmasına göre psikolojik güçlendirme işyerinde bireysel ve örgütsel motivasyon için önemli bir yaklaşımdır. Bu çalışmaya göre ayrıca psikolojik güçlendirme, iş tatmini ve örgütsel adanmışlık gibi örgütsel davranış kavramlarıyla güçlü derecede ilişkilidir. Dolayısıyla bir örgütün yüksek performans göstermesi ve devamlılığı için çalışanların psikolojik yönden güçlendirilmeleri önemlidir. Bunun yanında, çevresel zorluklar karşısında sorumluluk alan, bilgi paylaşımından korkmayan, kendileri ve diğer çalışanlar için ayağa kalkıp fikirlerini savunabilen bireylere de ihtiyaç vardır (Shojaie, Matin, \& Barani, 2011; Vakola \& Bouradas, 2005).

Örgütsel sessizlik, Morrison ve Milliken (2000) tarafından çalışanların örgütsel sorunlar hakkındaki görüşlerini ve endişelerini belirtmemeleri olarak tanımlanmaktadır. Onlara göre örgütsel sessizlik, örgütsel değişimin ve gelişmenin önündeki tehlikeli bir engel ve çoğulcu bir örgüt geliştirmenin önünü tıkayan, kolektif bir fenomen olarak tanımlamaktadırlar. Örgüt için negatif bir davranış olarak görülen örgütsel sessizlik konusunda Dyne, Ang ve Botero (2003) 3 boyutlu bir ölçe aracı geliştirmiştir.

Buna göre ilk olarak kabullenici sessizlik, çalışanın olan biteni kabullendiği için işe yarayabilecek fikirlerini, bilgi ve görüşlerini saklamasıdır. İkinci olarak savunma amaçlı Sessizlik, çalışanın duyduğu korkudan dolayı kurumunu ilgilendiren yararlı bilgileri ve fikirlerini kendini koruma amacıyla saklamasıdır. Son olarak kurum yararına sessizlik ise çalışanın, diğer insanların veya kurumun faydalanması amacıyla işe ilişkin fikirlerini, bilgiyi veya düşüncelerini saklamasıdır (Dyne vd., 2003). Örgüt çalışanlarının kabullenici ve savunma amaçlı sessizlik düzeylerinin düşük, kurum yararına sessizlik davranışının ise yüksek olması beklenir. Morrison ve Milliken'e (2000) göre birçok araştırmada çalışanların dikey iletişim kurmaları örgüt sağlığı açısından son derece önemlidir ancak birçok çalışan sorunlar hakkında bu tür bir iletişim kuramadıklarını belirtmektedirler. Hâlbuki yönetim kuramlarının güçlendirmeye ve daha açık iletişim kanallarına odaklandığı bir dönemde bu durum bir paradokstur.

Türkiye'de son 5 yılda eğitim ve öğretim alanında örgütsel sessizlik konusunda 6's1 doktora düzeyinde olmak üzere toplam 41 tez yapılmıştır. Yükseköğretimde sessizlik, nedenleri ve sonuçlarıyla (Algın, 2014) birlikte, örgütsel güven (Cakinberk, Dede, \& Yilmaz, 2014), örgütsel destek (Akçin, Erat, Alniaçik, \& Çiftçioğlu, 2017), örgütsel sosyalleşme (Dönmez, 2016) ve tükenmişlik (Akın \& Ulusoy, 2016) gibi örgütsel davranış boyutlanyla birlikte çalışıldığı görülmektedir. Bununla birlikte çalışanların örgütsel sessizliğinin adanmışlık ve iş tatminini negatif yönde etkilediği bulunmuştur (Vakola \& Bouradas, 2005).

Örgütte çalışanların psikolojik yönden güçlendirilmeleri onların sorunlar karşısında fikirlerini açıkça sunmalarına olanak sağlayabilir. Psikolojik güçlendirme, çalışanların sessizlik davranışlarını azaltmalarını sağlayabilir. Dolayısıyla örgüt performansı ve başarısının arttırılmasında psikolojik güçlendirmenin yüksek, sessizliğin ise düşük olması son derece önemlidir. Bu araştırmanın genel amacı, eğitim fakültelerinde görev yapan öğretim elemanlarının psikolojik güçlendirilmelerinin örgütsel sessizlikleri üzerindeki etkisini ortaya koymaktır. Bu bağlamda aşağıdaki sorulara yanıt aranmıştır:

1. Eğitim fakültesi öğretim elemanlarının psikolojik güçlendirilmeleri ve örgütsel sessizlikleri ne düzeydedir?

2. Eğitim fakültesi öğretim elemanlarının psikolojik güçlendirme ve örgütsel sessizlik düzeyleri cinsiyet, üniversite, unvan ve kıdem değişkenlerine göre anlamlı düzeyde farklılık göstermekte midir?

3. Eğitim fakültesi öğretim elemanlarının psikolojik güçlendirme puanları, örgütsel sessizlik puanlarını ne düzeyde yordamaktadır?

\section{Araştırmanın Modeli}

\section{YÖNTEM}

Araştırma tarama modelindedir. Araştırmada, eğitim fakültelerinde çalışan öğretim elemanlarının psikolojik güçlendirilmelerinin örgütsel sessizlik davranışları üzerindeki etkisini ortaya koymak amaçlanmıştır. 


\section{Evren-Örneklem}

Araştırmanın evrenini, 2017-2018 eğitim öğretim yılında Muğla Sıtk1 Koçman Üniversitesi, Adnan Menderes Üniversitesi ve Pamukkale Üniversitesi Eğitim Fakültelerinde görev yapan 380 akademisyen oluşturmaktadır. Örneklemin belirlenmesinde oransız küme örneklemesi tekniği kullanılmıştır. Evreni temsil edecek örneklem sayısı \%95 güven düzeyi için en az 191 olarak hesaplanmıştır. 200 ölçek formu gönderilmiştir. Ancak araştırma kapsamında uygulanan ölçeklerden 155 tanesi geri dönmüştür. Bu say1 \%6.22'lik hata payı ile kabul edilebilir bir örneklem sayısıdır (Meeker, Hahn, \& Escobar, 2017). Bu anlamda ulaşılan akademisyen oranı \%40.7'dir. Analizler kullanılabilir durumda olan 147 ölçekle yapılmıştır. Aşağıdaki tabloda örneklem grubunun özellikleri yer almaktadır.

Tablo 2. Örneklem Grubunun Özellikleri

\begin{tabular}{llll}
\hline Değişken & Gruplar & n & \% \\
\hline \multirow{2}{*}{ Üniversite } & Pamukkale Üniversitesi & 49 & 33.3 \\
& Adnan Menderes Üniversitesi & 35 & 23.8 \\
& Muğla Sitkı Koçman Üniversitesi & 63 & 42.9 \\
\hline \multirow{2}{*}{ Cinsiyet } & Kadın & 68 & 46.3 \\
& Erkek & 79 & 53.7 \\
\hline \multirow{3}{*}{ Unvan } & Araştırma görevlisi & 57 & 38.8 \\
& Doktor Öğretim Üyesi & 52 & 35.4 \\
& Doçent & 27 & 18.4 \\
\multirow{2}{*}{ Kidem } & Profesör & 11 & 7.5 \\
\hline
\end{tabular}

Tablo 2'de görüldüğü üzere araştırmaya katılan eğitim fakültesi öğretim elemanlarının \%33.3’ü Pamukkale Üniversitesinde ( $\mathrm{n}=49)$, \%23.8'i Adnan Menderes Üniversitesinde $(\mathrm{n}=35)$ ve \%42.9'u Muğla Sitk1 Koçman Üniversitesinde çalışmaktadır $(n=63)$. Öğretim elemanlarının \%46.3'ü kadın $(n=68), \% 53.8^{\prime} i$ erkektir $(n=79)$. Araştırmaya katılan öğretim elemanlarının \%38.8'i araştırma görevlisi $(n=57), \% 35$ 'i doktor öğretim üyesi $(n=52)$, $\% 18.4$ 'ü doçent $(n=27)$ ve $\% 7.5$ 'i profesördür $(n=11)$. Öğretim elemanlarının hizmet süreleri 1 ile 34 yıl arasında değişmektedir. Öğretmenlerin \%47.6'sı $(\mathrm{n}=70) 10$ yıl ya da daha az, \%52.4'ü $(\mathrm{n}=77) 11$ yıl ve üzerinde kıdeme sahiptir.

\section{Veri Toplama Araçları}

Araştırmada veri toplama aracı olarak Psikolojik Güçlendirme Ölçeği ve Örgütsel Sessizlik Ölçeği kullanılmıştır.

\section{Psikolojik Güçlendirme Ölçeği}

Psikolojik güçlendirme ölçeği, Spreitzer (1995) tarafından geliştirilmiş ve ölçeğin Türkçeye uyarlaması Sürgevil, Tolay ve Topoyan (2013) tarafından yapılmıştır. Ölçekte psikolojik güçlendirme; anlamlılık, yeterlilik, özerklik ve etki 3'er madde ile dört alt boyutta 12 likert tipi madde ile ölçülmektedir. Ölçekteki ifadeler "(1) Kesinlikle katılmıyorum" ve "(5) Kesinlikle katılıyorum” aralığında yanıtlanmaktadır. Her bir faktörden alınan yüksek puan, psikolojik güçlendirmenin arttığına işaret etmektedir. Ölçekte ters madde bulunmamaktadır. Ölçekten toplam puan alınabilmektedir. Spreitzer (1995) PGÖ'nün bütününe ilişkin Cronbach alfa değerini .72 olarak rapor etmiştir. Uyarlanmış ölçeğin DFA uyum değerleri kabul edilir sınırlar içerisindedir $\left(\chi^{2}=78.42, \mathrm{sd}=70, \chi^{2} / \mathrm{sd}=1.12\right.$, RMSEA= 0.022, $\mathrm{CFI}=1.00, \mathrm{GFI}=0.98, \mathrm{AGFI}=0.98)$. Bu araştırma için psikolojik güçlendirmenim her bir alt boyutu için Cronbach Alpha iç tutarlılık katsayıları; etki için .81, yeterlilik için .77, anlamlılık için .81, özerklik için ise .91 olarak bulunmuştur. Çalışmada ölçeğin toplam iç tutarlılığı ise .81 olarak hesaplanmıştır.

\section{Örgütsel Sessizlik Ölçeği}

Örgütsel sessizlik ölçeği, Dyne, Ang ve Botero (2003) tarafından geliştirilmiş ve ölçeğin Türkçeye uyarlaması Çolak, Yorulmaz, Türkkaş-Anasız, Dumlu ve Çiçek-Sağlam (2017) tarafından yapılmıştır. Ölçekte örgütsel sessizlik; kabullenici sessizlik, savunma amaçlı sessizlik ve kurum yararına sessizlik 5'er madde ile üç alt boyutta 15 likert tipi madde ile ölçülmektedir. Ölçekteki ifadeler "(1) Hiçbir zaman” ve "(5) Her zaman” aralı̆̆ında yanıtlanmaktadır. Her bir faktörden alınan yüksek puan, örgütsel sessizliğin arttığına işaret etmektedir. Ölçekte ters madde bulunmamaktadır. Ölçekten toplam puan alınamamaktadır. Kabullenici sessizlik alt boyutunda çalışanın olan biteni 
kabullendiği için; savunma amaçlı sessizlik alt boyutunda ise çalışanın duyduğu korkudan dolayı sessizlik davranışı göstermesi söz konusudur. Kabullenici ve savunma amaçlı sessizlikten farklı olarak, kurum yararına sessizlikte çalışanlar başkaları veya kurum için duydukları kaygıdan dolayı sessiz kalmayı tercih ederler. Dolayısıyla ilk iki alt boyutta düşük puan düzeyleri; üçüncü alt boyutta ise yüksek puan düzeyi arzulanan bir çıktı olarak değerlendirilebilir. $\mathrm{Bu}$ yüzden boyutların tamamı toplam puan alınarak değerlendirilemez. Uyarlanmış ölçeğin DFA uyum değerleri kabul edilir sınırlar içerisindedir $\left(\chi^{2}=123.88, \mathrm{sd}=85, \chi^{2} / \mathrm{sd}=1.46, \mathrm{RMSEA}=0.04, \mathrm{CFI}=0.99, \mathrm{GFI}=0.95, \mathrm{AGFI}=0.93\right) . \mathrm{Bu}$ araştırma için sessizliğin her bir alt boyutu için Cronbach Alpha iç tutarlılık katsayıları; Kabullenici Sessizlik için .85, Savunma Amaçlı Sessizlik için .89 ve Kurum Yararına Sessizlik için .89 olarak hesaplanmıştır.

\section{Verilerin Analizi}

Öncelikle veri setinde kayıp veri analizi yapılmış ve kayıp verinin olmadığı belirlenmiştir. Tek yönlü uç değerlerin belirlenmesi için tüm değişkenlere ait z puanları hesaplanarak uç değer içeren 7 ölçek veri setinden çıkarılmıştır. Kutu grafiği kontrol edilmiştir, grafiğin dışında kalan aşırı uç değerin olmadığı görülmüştür. Çok yönlü uç değerlerin belirlenmesinde ise Mahalanobis uzaklıkları hesaplanmıştır. Buna göre çok yönlü uç değer olduğundan dolayı 1 ölçek veri setinden çıkarılmıştır. Dağılımın normalliği kontrol edildiğinde çarpıklık basıklık katsayıları -1.5 ile +1.5 aralığında olduğu için (Tabachnick \& Fidell, 2012) dağılımın normal olduğu söylenebilir. Araştırma verilerinin analizinde betimsel istatistikler, ikili karşılaştırmalarda t-testi, üç ve daha fazla boyutu olan karşılaştırmalarda tek yönlü varyans analizi kullanılmıştır. İstatistiksel olarak anlamlı bulunan değerler için, farkın kaynağını belirlemek üzere çoklu karşılaştırma testlerinden Tukey testi kullanılmıştır. Eğitim fakültesi öğretim elemanlarının psikolojik güçlendirme puanlarının, örgütsel sessizlik düzeylerini anlamlı bir şekilde yordayıp yordamadığını belirlemek için çoklu regresyon analizi kullanılmıştır.

\section{Bulgular}

Bu bölümde eğitim fakültesi öğretim elemanlarının psikolojik güçlendirme ve örgütsel sessizlik davranışlarına ilişkin görüşlerine ve bu görüşlerin cinsiyet, üniversite, unvan ve kıdem değişkenlerine göre farklılaşıp farklılaşmadığına bakılmıştır. Daha sonra eğitim fakültesi öğretim elemanlarının psikolojik güçlendirilmelerinin örgütsel sessizlik davranışını anlamlı bir şekilde yordayıp yordamadığına ilişkin regresyon analizi sonuçlarına yer verilmiştir.

Araştırmaya katılan eğitim fakültesi öğretim elemanları psikolojik güçlendirilmeleri $(x=3.92, S=.45)$ orta düzeyin üzerindedir. Öğretim elemanları, psikolojik güçlendirme boyutlarından en çok anlamlılık boyutunda güçlendirilmişlerdir ( $x=4.46, \mathrm{~S}=.59)$. Bunu sırası ile özerklik $(\mathrm{x}=3.95, \mathrm{~S}=.72)$, yeterlilik $(4=3.50, \mathrm{~S}=.47)$, ve etki $(x=2.76, S=.90)$ boyutları takip etmektedir. Öğretim elemanlarının psikolojik güçlendirilmeleri tüm alt boyutlarında ve toplam puanda, cinsiyet, hizmet süresi ve üniversite değişkenine göre farklılaşmamaktadır. Unvan değişkenine göre psikolojik güçlendirmenin özerklik $[\mathrm{F}(2-144)=3.95 ; \mathrm{p}<.05]$ ve etki $[\mathrm{F}(2-144)=2.76 ; \mathrm{p}<.05]$ alt boyutlanyla toplam puanda $[\mathrm{F}(2-144)=3.92 ; \mathrm{p}<.05]$ farklılaştığı görülmektedir. Doktor öğretim üyesi kadrosundaki öğretim elemanlarının psikolojik güçlendirmenin alt boyutu "özerklik" puanları $(\mathrm{x}=4.18, \mathrm{~S}=.65)$, araştırma görevlisi kadrosundaki öğretim elemanlarının puanlarından $(\mathrm{x}=3.66, \mathrm{~S}=.74)$ anlamlı derecede daha yüksektir. Profesör kadrosundaki öğretim elemanlarının psikolojik güçlendirmenin alt boyutu "etki" puanları ( $\mathrm{x}=3.33, \mathrm{~S}=.85)$, araştırma görevlisi kadrosundaki öğretim elemanlarının puanlarından ( $\mathrm{x}=2.57, \mathrm{~S}=.87)$ anlamlı derecede daha yüksektir. Toplam psikolojik güçlendirme puanlarına bakıldığında, doktor öğretim üyesi kadrosundaki öğretim elemanlarının psikolojik güçlendirmenin puanları $(\mathrm{x}=4.03, \mathrm{~S}=.44)$, araştırma görevlisi kadrosundaki öğretim elemanlarının puanlarından $(\mathrm{x}=3.75, \mathrm{~S}=.47)$ anlamlı derecede daha yüksektir.

Öğretim elemanları, örgütsel sessizlik boyutlarından kabullenici sessizlikte ( $x=2.09, \mathrm{~S}=.76)$ en düşük puanı almışlardır. Bunu savunma amaçlı sessizlik $(\mathrm{x}=2.22, \mathrm{~S}=.83)$ takip ederken kurum yararına sessizlik $(\mathrm{x}=4.26, \mathrm{~S}=.68)$ alt boyutunda en yüksek puanı almışlardır. Öğretim elemanlarının sessizlik davranışı tüm alt boyutlarda cinsiyet, hizmet süresi ve unvan değişkenine göre farklılaşmamaktadır. Üniversite değişkenine göre örgütsel sessizliğin savunma amaçlı sessizlik $[\mathrm{F}(2-144)=3.44 ; \mathrm{p}<.05]$ alt boyutunda farklılaşmaktadır. Adnan Menderes Üniversitesi eğitim fakültesi öğretim elemanlarının ( $\mathrm{x}=4.63, \mathrm{~S}=.61$ ), savunma amaçlı sessizlik alt boyutundaki puanları $(\mathrm{x}=2.53, \mathrm{~S}=.98)$; Pamukkale Üniversitesi Eğitim fakültesi öğretim elemanlarınınkinden $(x=2.08, S=.78)$ daha yüksektir. Sessizliğin kabullenici sessizlik $[\mathrm{F}(2-144)=2.12 ; \mathrm{p}>.05]$ ve kurum yararına sessizlik $[\mathrm{F}(2-144)=1.66 ; \mathrm{p}>.05]$ boyutlarında farkl111k göstermemektedir. 
Araştırmanın son amacı eğitim fakültesi öğretim elemanlarının psikolojik güçlendirilmelerinin örgütsel sessizlik davranışını anlamlı bir şekilde yordayıp yordamadığının belirlenmesidir. Bu çerçevede çoklu regresyon analizinden yararlanılmıştır. Analiz sonucunda psikolojik güçlendirmenin eğitim fakültesi öğretim elemanlarının örgütsel sessizlik davranışı üzerindeki etkisi sınanmıştır. Aşağıdaki tablolarda örgütsel sessizlik davranışının yordanmasına ilişkin regresyon analizi sonuçları yer almaktadır.

Tablo 3. Kabullenici Sessizlik Davranışının Yordanmasına İlişkin Regresyon Analizi Sonuçları

\begin{tabular}{|c|c|c|c|c|c|c|c|c|}
\hline Değişen & B & Standart Hata & $\beta$ & $\mathrm{t}$ & $\mathrm{p}$ & İkili (r) & $\begin{array}{r}\text { Kismi } \\
(\mathrm{r})\end{array}$ & VIF \\
\hline Sabit & 4.676 & .60 & - & 7.79 & .00 & - & - & \\
\hline Anlamlil1k & -.41 & .10 & -.32 & -3.89 & .00 & -.38 & .31 & 1.24 \\
\hline Yeterlilik & .04 & .13 & .02 & .31 & .75 & -.15 & -.02 & 1.23 \\
\hline Özerklik & -.07 & .08 & -.06 & -.83 & 40 & -.23 & -.07 & 1.25 \\
\hline Etki & -.22 & .06 & -.26 & -3.44 & .00 & -.33 & -.27 & 1.07 \\
\hline \multicolumn{9}{|c|}{$\mathrm{R}=0.47, \mathrm{R}^{2}=0.22, \mathrm{~F}_{(4-142)}=10.32, \mathrm{p}=0.00$} \\
\hline
\end{tabular}

Tablo 3 incelendiğinde, psikolojik güçlendirmenin anlamlılık, yeterlilik, özerklik ve etki boyutlarının birlikte kabullenici sessizlik davranışı ile anlamlı bir ilişki verdiği görülmektedir $(\mathrm{R}=.47, \mathrm{p}<.05)$. Bu yordayıcı değişkenler, eğitim fakültesi öğretim elemanlarının kabullenici sessizlik davranışlarındaki toplam varyansın \%22'sini açıklamaktadır. Anlamlılık $(\beta=-.32, \mathrm{p}<.05)$ ve etki $(\beta=-.26, \mathrm{p}<.05)$, kabullenici sessizliği negatif yönde ve anlamlı düzeyde yordamaktadır. Yeterlilik $(\beta=.02, \mathrm{p}>.05)$ ve özerklik $(\beta=-.06, \mathrm{p}>.05)$ ise, kabullenici sessizliğin anlamlı yordayıcısı değildir.

Tablo 4. Savunma Amaçlı Sessizlik Davranışının Yordanmasına İlişkin Regresyon Analizi Sonuçları

\begin{tabular}{|c|c|c|c|c|c|c|c|c|}
\hline Değişen & $\mathrm{B}$ & Standart Hata & $\beta$ & $\mathrm{t}$ & $\mathrm{p}$ & İkili (r) & $\begin{array}{r}\text { Kismi } \\
(\mathrm{r}) \\
\end{array}$ & VIF \\
\hline Sabit & 4.96 & .68 & - & 7.30 & .00 & - & - & \\
\hline Anlamlllık & -.10 & .12 & -.07 & -.85 & .39 & -.22 & -.07 & 1.24 \\
\hline Yeterlilik & -.17 & .15 & -.09 & -1.13 & .25 & -.23 & -.09 & 1.23 \\
\hline Özerklik & -.27 & .09 & -.24 & -2.81 & .00 & -.33 & -.23 & 1.25 \\
\hline Etki & -.14 & .07 & -.16 & -2.01 & .05 & -.24 & -.16 & 1.07 \\
\hline \multicolumn{9}{|c|}{$\mathrm{R}=0.40, \mathrm{R}^{2}=0.16, \mathrm{~F}_{(4-142)}=6.77, \mathrm{p}=0.00$} \\
\hline
\end{tabular}

Tablo 4 incelendiğinde, psikolojik güçlendirmenin anlamlılık, yeterlilik, özerklik ve etki boyutlarının birlikte kabullenici savunma amaçlı sessizlik davranışı ile anlamlı bir ilişki verdiği görülmektedir $(\mathrm{R}=.40, \mathrm{p}<.05)$. Bu yordayıcı değişkenler, eğitim fakültesi öğretim elemanlarının savunma amaçlı sessizlik davranışlarındaki toplam varyansın \%16'sını açıklamaktadır. Özerklik $(\beta=-.24, p<.05)$, savunma amaçlı sessizliği negatif yönde ve anlamlı düzeyde yordamaktadır. Anlamlılık $(\beta=-.07, \mathrm{p}>.05)$, yeterlilik $(\beta=-.09, \mathrm{p}>.05)$ ve etki $(\beta=-.16, \mathrm{p}>.05)$ ise savunma amaçlı sessizliğin anlamlı yordayıcısı değildir.

Tablo 5. Kurum Yararına Sessizlik Davranışının Yordanmasına İlişkin Regresyon Analizi Sonuçları

\begin{tabular}{|c|c|c|c|c|c|c|c|c|}
\hline Değişen & $\bar{B}$ & Standart Hata & $\beta$ & $\mathrm{t}$ & $\mathrm{p}$ & İkili (r) & $\begin{array}{r}\begin{array}{r}\text { Kismi } \\
(\mathrm{r})\end{array} \\
\end{array}$ & $\overline{\mathrm{VIF}}$ \\
\hline Sabit & 2.38 & .58 & - & 4.08 & .00 & - & - & \\
\hline Anlamlilık & .12 & .10 & .11 & 1.23 & .21 & .18 & .10 & 1.24 \\
\hline Yeterlilik & .27 & .12 & .18 & 2.09 & .03 & .23 & .17 & 1.23 \\
\hline Özerklik & .03 & .08 & .03 & .43 & .66 & .13 & .03 & 1.25 \\
\hline Etki & -.02 & .06 & -.02 & -.34 & .73 & .03 & -.02 & 1.07 \\
\hline \multicolumn{9}{|c|}{$\mathrm{R}=0.26, \mathrm{R}^{2}=0.07, \mathrm{~F}_{(4-142)}=2.70, \mathrm{p}=0.03$} \\
\hline
\end{tabular}


Tablo 5 incelendiğinde, psikolojik güçlendirmenin anlamlılık, yeterlilik, özerklik ve etki boyutlarının birlikte kabullenici kurum yararına sessizlik davranışı ile anlamlı bir ilişki verdiği görülmektedir $(\mathrm{R}=.26, \mathrm{p}<.05)$. Bu yordayıcı değişkenler, eğitim fakültesi öğretim elemanlarının kurum yararına sessizlik davranışlarındaki toplam varyansın \%7'sini açıklamaktadır. Yeterlilik $(\beta=.18, \mathrm{p}<.05)$, kurum yararına sessizliği pozitif yönde ve anlamlı düzeyde yordamaktadır. Anlamlılık $(\beta=.11, \mathrm{p}>.05)$, özerklik $(\beta=.03, \mathrm{p}>.05)$ ve etki $(\beta=.02, \mathrm{p}>.05)$ ise kurum yararına sessizliğin anlamlı yordayıcısı değildir.

\section{Tartışma, Sonuç ve Öneriler}

Eğitim fakültelerinde görev yapan öğretim elemanlarının psikolojik güçlendirilmelerinin örgütsel sessizlikleri üzerindeki etkisini ortaya koymayı amaçlayan bu araştırmanın bulgularına göre, eğitim fakültesi öğretim elemanlarının psikolojik güçlendirilmeleri orta düzeyin üzerindedir. $\mathrm{Bu}$ sonuç akademisyenlerin psikolojik güçlendirmeleri konusunda alan yazındaki araştırma sonuçlarıyla benzerlik göstermektedir (Eydoğmuş vd., 2015; Jordan vd., 2017; Tolay vd., 2012). Dolayısıyla eğitim fakültelerinde çalışan öğretim elemanlarının kişisel kontrol algılarının ve motivasyonlarının yüksek olduğu söylenebilir. Öğretim elemanlarının psikolojik güçlendirilmeleri cinsiyet, hizmet süresi ve üniversite değişkenine göre farklılaşmamaktadır. Unvan değişkenine göre ise psikolojik güçlendirmenin özerklik ve etki alt boyutlarıyla toplam psikolojik güçlendirme puanlarının farklılaştığı görülmektedir. Doktor öğretim üyelerinin özerklik düzeyi araştırma görevlilerinkinden daha yüksektir. Profesörlerin etki düzeyleri araştırma görevlilerinkinden daha yüksektir. Toplam psikolojik güçlendirme puanlarına bakıldığında, doktor öğretim üyelerinin psikolojik güçlendirilmeleri araştırma görevlilerinin psikolojik güçlendirilmelerinden daha yüksek olduğu görülmektedir.

Öğretim elemanları, orta düzeyin altında kabullenici sessizlik ve savunma amaçlı sessizlik göstermektedirler. Öte yandan öğretim elemanlarının kurum yararına sessizlik puanları yüksektir. Bu anlamda öğretim elemanlarının işe yarayabilecek bilgi, fikir ve görüşlerini belirttikleri, değişiklik yaratmaya istekli oldukları ancak bununla birlikte bazı konularda ses çıkarmada birtakım kaygıların olduğu söylenebilir. Ayrıca öğretim elemanlarının, kurumunu ilgilendiren yararlı bilgileri ve fikirleri söylemekten çekinmediği de söylenebilir. Kabullenici sessizliği yüksek olan çalışanlar, değişim yaratabileceklerine ilişkin düşük öz yeterlik algıları dolayısıyla fikirlerini kendilerine saklarlar (Dyne vd., 2003). Kabullenici sessizlik ve savunma amaçlı sessizlik çalışan performansını negatif yönde, kurum yararına sessizlik ise pozitif yönde etkilemektedir (Dyne vd., 2003; Umar \& Hassan, 2013). Bununla birlikte kurum yararına olan yüksek sessizlik düzeyi, öğretim elemanları için bir fedakarlık ve işbirliği anlayışına dayanır. Diğer sessizlik boyutlarından farklı olarak kurum yararına sessizlik davranışı, çalışanlar veya kurum için duyulan kaygı yüzünden yüksektir. Öğretim elemanlarının sessizlik davranışı tüm alt boyutlarda cinsiyet, hizmet süresi ve unvan değişkenine göre farklılaşmamaktadır. Üniversite değişkenine göre ise Adnan Menderes Üniversitesi eğitim fakültesi öğretim elemanlarının savunma amaçlı sessizlik düzeylerinin Pamukkale Üniversitesi Eğitim Fakültesi öğretim elemanlarınınkinden daha yüksek olduğu görülmektedir. Bu durumda Adnan Menderes Üniversitesi eğitim fakültesi öğretim elemanlarının kendilerini koruma duyguları ve ortaya çıkacak problemlerde sorumlu tutulacakları endişesiyle orta düzeye yakın savunma amaçlı sessizlik davranışı gösterdikleri söylenebilir.

Psikolojik güçlendirmenin anlamlılık ve etki alt boyutları ile kabullenici sessizlik arasında negatif yönde bir ilişki vardır. Başka bir ifadeyle öğretim elemanlarının yaptıkları işi önemseme ve işyerindeki örgütsel sonuçlar üzerinde etki düzeyi arttıkça, olan biteni kabullenme, bilgi ve görüşlerini saklama davranışı azalacaktır. Bu bulgunun psikolojik güçlendirmenin ve örgütsel sessizliğin örgüt performansı üzerindeki etkisini ortaya koyduğu söylenebilir. Psikolojik güçlendirme, eğitim fakültesi öğretim elemanlarının kabullenici sessizlik davranışlarının \%22'sini açıklamaktadır. Psikolojik güçlendirmenin özerklik boyutu ile savunma amaçlı sessizlik arasında negatif yönde bir ilişki vardır. Dolayısıyla öğretim elemanlarının işlerini nasıl yapacakları konusunda karar verme özgürlükleri ve işleri üzerinde kontrolleri arttıkça kendini koruma duygusu ve ortaya çıkacak problemlerden sorumlu tutulma endişesinin azalacaktır. Psikolojik güçlendirme, eğitim fakültesi öğretim elemanlarının savunma amaçlı sessizlik davranışlarının \%16'sını açıklamaktadır. Psikolojik güçlendirmenin yeterlilik boyutu ile kurum yararına sessizlik arasında pozitif yönde bir ilişki vardır. Öğretim elemanlarının işlerini iyi yapabilmeleri konusunda kendilerine ve yeteneklerine güven düzey arttıkça, diğer çalışanlar ve kurum için duyulan kaygı yüzünden kurum yararına sessizlik davranışı artacaktır. Psikolojik güçlendirme, eğitim fakültesi öğretim elemanlarının kurum yararına sessizlik davranışlarının \%7'sini açıklamaktadır. 
Psikolojik güçlendirme çeşitli bağlamlarda farklı şekiller alabilir (Zimmerman, 1995). Bu anlamda yükseköğretimdeki çalışanların yüksek düzeyde psikolojik güçlendirilmeleri son derece önemlidir. Çünkü yüksek düzeyde psikolojik güçlendirilme, çalışanların işlerini yapma konusunda kendilerini yeterli hissetmeleri, işyerindeki kararlar konusunda etkilerinin olması, işlerini önemli görmesi ve kendilerini etkili ve yeterli görmesi olarak tanımlanabilir (Jordan vd., 2017). Avan ve diğerleri (2016) otel çalışanlarıyla yaptıkları psikolojik güçlendirme ve örgütsel sessizlik ilişkisi çalışmasında bu iki değişken arasında düşük düzeyde anlamlı ilişki bulmuşladır. Psikolojik güçlendirilmeleri yüksek çalışanların iş doyumu (Chang, Shih, \& Lin, 2010; Seibert vd., 2011), örgütsel adanmışlık düzeyleri (Chang vd., 2010), örgütsel vatandaşl1k düzeylerinin (Çavuşoğlu \& Güler, 2017) de yüksek olduğu bilinmektedir. Yüksek örgütsel sessizlik davranışı, psikolojik güçlendirme ile ilişkili olan ve örgüt performansını yükselten diğer örgütsel davranışların aksine örgütün gelişimi ve ilerlemesi için bir engel olarak görülebilir.

Öğretim elemanlarının psikolojik güçlendirilmeleri yüksek düzeyde çıkmadığı için alt boyutlardan hareketle öğretim elemanlarının yetiştirilmesi, gelişmesi, kurumsal düzeyde karara katılma, işiyle ilgili hususlarda özgür hareket edebilmesi gibi hususlarda kurum yönetiminin destekleyici bir kurum kültürü oluşturması yararlı olabilir. Ayrıca, kabullenici sessizlik ve savunma amaçlı sessizlik alt boyutlarında öğretim elemanlarının orta düzeyin altında görüş belirtmeleri de bu konuda önlem alınması gerektiğini göstermektedir. Sessizliğe yol açan hususların belirlenmesi ve önlem alınması kurumsal amaçların gerçekleşmesi açısından önemli görülmektedir. Bu araştırmadaki başlıca sınırlılık araştırmaya katılanların üç kamu üniversitesi eğitim fakültesinde çalışan öğretim elemanları ile sınırlı tutulmasıdır. Özel üniversitelerdeki ve diğer kamu üniversitelerindeki eğitim fakültelerinde çalışan öğretim elemanlarının psikolojik güçlendirilmeleri ve örgütsel sessizlik davranışları konusunda bilgi edinilmemiştir. 


\section{Extended Summary}

\section{Introduction}

Having the primary responsibility for teacher education, education faculties are under pressure to improve performance. One of the key elements in performance improvement is the lecturers working in education faculties, as the individuals within institutions are the main factor for survival in an environment that is highly competitive and plays a major part in the productivity of the institution (Jomah, 2017). Psychological empowerment (Spreitzer, 1995) and organizational silence are critical organizational behaviors necessary for the change and performance improvement in organizations. An important determinant of empowerment is whether individuals prefer to speak up instead of maintaining silent behavior and individuals speaking up about organizational issues and problems play a crucial role in organizational success (Avan, Zorlu, \& Baytok, 2016). Psychological empowerment enhances individuals' self-control perception and motivation, thus achieving positive organizational and managerial outcomes (Quinn \& Spreitzer, 1997). Psychological empowerment exists when employees perceive that they exercise some control over their work life (Spreitzer, 1995). Organizational silence can affect the performance of organizations positively or negatively (Bagheri, Zarei \& Aeen, 2012). The purpose of this study is to determine the effect of psychological empowerment on organizational silence behaviors of education faculty lecturers. To achieve this aim, the following questions are addressed:

1- What are the levels of psychological empowerment and organizational silence of education faculty lecturers?

2- Do the lecturers' psychological empowerment and organizational silence behaviors differ significantly according to the variables of university, gender, title, and seniority?

3- Is the psychological empowerment level of lecturers a significant predictor of their organizational silence behaviors?

\section{Methodology}

The sample of this descriptive study consists of 147 lecturers working in education faculties at Mugla Sitki Kocman University, Adnan Menderes University and Pamukkale University. The data of the study were collected through the administration of the psychological empowerment and organizational silence behavior scales. The Psychological Empowerment Scale was developed by Spreitzer (1995). Spreitzer has investigated the perceptions of employees regarding their psychological empowerment in four dimensions, namely meaning, competence, self-determination and impact. This scale was adapted into Turkish by Sürgevil, Tolay, \& Topoyan (2013). The Organizational Silence Scale was developed by Dyne, Ang, and Botero (2003) and adapted into Turkish by Çolak, Yorulmaz, Türkkaş-Anasız, Dumlu, and Çiçek-Sağlam (2017). This scale consists of three sub-dimensions: acquiescent silence, defensive silence, and prosocial silence. Higher scores in psychological empowerment mean that the lecturers in an education faculty are empowered in a positive way, while higher scores in the organizational silence behavior scale mean that education faculty lecturers are more silent. In the analysis of the data, descriptive statistics, $t$ test, ANOVA and multiple regression analysis were conducted.

\section{Findings}

The findings of the study show that the lecturers in education faculties are psychologically empowered above the medium level $(\mathrm{x}=3.92, \mathrm{~S}=.45)$ and show acquiescent silence at the minimum level $(\mathrm{x}=2.09, \mathrm{~S}=.76)$. According to the findings of the study, there were no significant differences in lecturers' psychological empowerment in terms of gender, seniority, and university. However, the self-determination level of assistant professors is significantly higher than for research assistants. The impact level of professors is also significantly higher than for research assistants. In total, assistant professors have a significantly higher level of psychological empowerment than research assistants. There were no significant differences in lecturers' organizational silence behaviors in terms of gender, seniority, and title. Psychological empowerment explains 22 percent of acquiescent silence, 16 percent of defensive silence, and 7 percent of prosocial silence behaviors of lecturers working in education faculties. 


\section{Conclusions}

A substantial body of research has accumulated during the past decades redefining the conceptual domain of psychological empowerment and investigating its antecedents and consequences. Psychological empowerment was measured in relation to different variables. Individuals with high levels of psychological empowerment have higher levels of job satisfaction (Chang, Shih, \& Lin, 2010; Seibert, Wang, \& Courtright, 2011), organizational commitment (Chang et al., 2010), and organizational citizenship (Çavuşoğlu \& Güler, 2017). Organizational silence is thought to be an obstacle for performance improvement in organizations. The findings of the study show that lecturers working in education faculties are psychologically empowered above the medium level which is a similar result to the related literature (Eydoğmuş, Ergeneli, \& Camgoz, 2015; Jordan, Miglič, Todorović, \& Marič, 2017; Tolay, Sürgevil, \& Topoyan, 2012) and participants show low levels of acquiescent silence and defensive silence behaviors but a high level of prosocial silence, which is good for the institution. Psychological empowerment is a significant predictor of organizational silence behaviors of lecturers working in education faculties at different levels. The primary limitation of this study was the sample of the study. The participants are all education faculty lecturers working at three state universities in Turkey. Psychological empowerment and organizational silence behaviors of lecturers working at different faculties and private universities may show different results. 


\section{Kaynakça / References}

Akçin, K., Erat, S., Alniaçik, Ü. \& Çiftçioğlu, A. B. (2017). Effect of perceived organizational support on organizational silence and task performance: A study on academicians. Journal of Global Strategic Management, 11(1), 151-151. doi:10.20460/JGSM.20161024363

Akgündüz, Y., Kale, A. \& Pazarbaşı, G. (2014). Futbol turizmine hizmet eden otel çalışanlarının psikolojik güçlendirme algılarının örgütsel vatandaşlık davranışlarına etkisi. Mustafa Kemal University Journal of Graduate School of Social Sciences, 11(28), 1-15.

Akın, U. \& Ulusoy, T. (2016). The relationship between organizational silence and burnout among academicians: A research on universities in Turkey. International Journal of Higher Education, 5(2), 46-58. doi:10.5430/ijhe.v5n2p46

Algın, İ. (2014). Üniversitelerde örgütsel sessizlik (Yayımlanmamış yüksek lisans tezi). Hacettepe Üniversitesi, Ankara.

Altınkurt, Y., Türkkaş-Anasız, B., \&ve Ekinci, E. C. (2016). Öğretmenlerin yapısal ve psikolojik güçlendirilmeleri ile örgütsel vatandaşlık davranışları arasındaki ilişki. Eğitim ve Bilim, 41(187), 393-404. doi:10.15390/EB.2014.3595

Arslantaş, C. C. (2007). Dönüşümcü liderliğin psikolojik güçlendirme ve örgütsel vatandaşlık davranışı üzerindeki etkisi. Amme İdaresi Dergisi, 40(4), 81-101.

Avan, A., Zorlu, Ö., \& Baytok, A. (2016). The effect of psychological empowerment on organizational silence in hotels. Journal of Business Research - Turk, 8(4), 277-277. doi:10.20491/isarder.2016.219

Bagheri, G., Zarei, R., \& Aeen, M. N. (2012). Organizational silence: Basic concepts and its development factors. Ideal Type of Management, 1(1), 47-58.

Bandura, A. (1982). The assessment and predictive generality of self-percepts of efficacy. Journal of Behavior Therapy and Experimental Psychiatry, 13(3), 195-199.

Bolat, T., Bolat, O. İ., \& Yüksel, M. (2016). Hizmetkar liderlik ve psikolojik güçlendirme ilişkisi: Örgüt kültürünün düzenleyici etkisi. Balıkesir University The Journal of Social Sciences Institute, 19(36), 75-104.

Cakinberk, A. K., Dede, N. P., \& Yilmaz, G. (2014). Relationship between organizational trust and organizational silence: An example of public university. Journal of Economics, Finance and Accounting, 1(2), 91-105.

Çalışkan, S. C. (2011). Çalışanların psikolojik güçlendirme algıları üzerinde işyeri arkadaşlıkları ve örgütsel iletişimin etkisi. Ç.Ü. Sosyal Bilimler Enstitüsü Dergisi, 20(3), 77-92.

Çavuşoğlu, F., \& Güler, M. E. (2017). Psikolojik güçlendirme ile örgütsel vatandaşlık davranışının ilişkisi ve demografik değişkenlere göre farklılıkları: İzmir şehir merkezindeki konaklama işletmelerinde bir araştırma. Journal of Travel and Hospitality Management, 14(2), 47-64.

Chang, L. C., Shih, C. H., \& Lin, S. M. (2010). The mediating role of psychological empowerment on job satisfaction and organizational commitment for school health nurses: A cross-sectional questionnaire survey. International Journal of Nursing Studies, 47(4), 427-433. doi:10.1016/j.ijnurstu.2009.09.007

Çolak, İ., Yorulmaz, Y. İ., Türkkaş-Anası, B., Dumlu, N., \& Çiçek-Sağlam, A. (2017). Örgütsel sessizlik ölçeğinin 
Türkçeye uyarlanması: Geçerlik ve güvenirlik çalışması. Muğla: 2. Uluslararası Çağdaş Eğitim Araştırmaları Kongresi.

Conger, J. A., \& Kanungo, R. N. (1988). The empowerment process : Integrating theory and practice. Academy of Management Journal, 13(3), 471-482.

Dönmez, E. (2016). Örgütsel sosyalleşme ile örgütsel sessizlik arasindaki ilişki (Yayımlanmamış yüksek lisans tezi). Pamukkale Üniversitesi, Denizli.

Dyne, L. Van, Ang, S., \& Botero, I. C. (2003). Conceptualizing employee silence and employee voice as multidimensional constructs. Journal of Management Studies, 40(6), 1359-1392. doi:10.1111/14676486.00384

Erdem, H., Gökmen, Y., \& Türen, U. (2016). Psikolojik güçlendirme boyutlarının iş performansı üzerine etkisinde örgütsel bağl1lı̆̆ın aracılık rolü: Görgül bir araştırma. Doğuş Üniversitesi Dergisi, 17(2), 161-176.

Eydoğmuş, C., Ergeneli, A., \& Camgoz, S. M. (2015). The role of psychological empowerment on the relationship between personality and job satisfaction. Research Journal of Business and Management, 2(3), 251-251. doi:10.17261/Pressacademia.2015312979

Fettahlıŏlu, Ö. O., \& Sünbül, M. B. (2015). Duygusal zekanın psikolojik güçlendirme üzerindeki etkisi. Akademik Sosyal Araştırmalar Dergisi, 3(14), 157-175. https://www.scopus.com/inward/record.uri?eid=2-s2.079955603396\&partnerID=40\&md5=448efebb766dc488b3c3686cfl aa5ce3 adresinden erişildi.

Gümüş, A. (2013). Illkokul yöneticilerinde güçlendirici liderlik davranışları ile öğretmenlerde örgütsel bağlllı ilişsisi: Psikolojik güçlendirmenin aracılık rolü (Ankara ili örneği) (Yayımlanmamış yüksek lisans tezi). Gazi Üniversitesi, Ankara.

İşcan, Ö. F., \& Çakır, S. (2016). Mentorluk ve psikolojik güçlendirmenin öz yeterlilik algısına etkisi. Suleyman Demirel University The Journal of Faculty of Economics and Administrative Sciences, 21(1), 1-15.

Jomah, N. Bin. (2017). Psychological empowerment onorganizational commitment as perceived by Saudi academics. World Journal of Education, 7(1), 83. doi:10.5430/wje.v7n1p83

Jordan, G., Miglič, G., Todorović, I., \& Marič, M. (2017). Psychological empowerment, job satisfaction and organizational commitment among lecturers in higher education: Comparison of six CEE countries. Organizacija, 50(1), 17-32. doi:10.1515/orga-2017-0004

Karakaş, A., \& Serçek, S. (2014). Psikolojik güçlendirme algısının örgütsel bağl1lığa etkisi: Otel çalışanları üzerine bir araştırma. Journal of Travel and Hospitality Management, 11(2), 90-107.

Meeker, W. Q., Hahn, G. J., \& Escobar, L. A. (2017). Statistical intervals: A guide for practitioners and researchers. John Wiley \& Sons. (2. bs.). Hoboken, New Jersey: JohnWiley \& Sons. doi:10.1002/9781118594841

Morrison, E. W., \& Milliken, F. J. (2000). Organizational silence: A barrier to Change and development in a Pluralistic world. Academy of Management Review, 25(4), 706-725. doi:10.5465/AMR.2000.3707697

Nartgün, Ş. S., \& Demirer, S. (2017). Okul yöneticilerinin psikolojik güçlendirme ve örgütsel imaj algıları arasındaki 
ilişki. The Journal of Academic Social Science Studies International, (57), 39-65. doi:10.9761/JASSS6938

Odabaş, İ. (2014). Yapısal güçlendirme ile örgütsel bağlllık arasındaki ilişkide psikolojik güçlendirmenin ara değişken rolü: Öğretmenler üzerinde bir çalışma. İstanbul Kültür.

Oktuğ, Z. (2017). Psikolojik güçlendirme algısı ile örgütsel bağlılık arasındaki ilişkide bireycilik-toplulukçuluk eğilimlerinin biçimlendirici rolü. AIBBÜ Sosyal Bilimler Enstitüsü Dergisi, 17(3), 245-266.

Othman, A., \& Barakat, A. (2016). Psychological empowerment and its relationship to perceived academic selfefficiency among faculty of Najran University. Journal of Research \& Method in Education, 6(1), 14-22. doi:10.9790/7388-06121422

Quinn, R., \& Spreitzer, G. (1997). Seven questions every leader should consider. Organizational Dynamics, 26(2), 37-49. doi:10.1016/S0090-2616(97)90004-8

Safari, K., Haghighi, A. S., Rastegar, A., \& Jamshidi, A. (2011). The relationship between psychological empowerment and organizational learning. Procedia - Social and Behavioral Sciences, 30, 1147-1152. doi:10.1016/j.sbspro.2011.10.224

Seibert, S. E., Wang, G., \& Courtright, S. H. (2011). Antecedents and consequences of psychological and team empowerment in organizations: A Meta-analytic review. Journal of Applied Psychology, 96(5), 981-1003. doi:10.1037/a0022676

Shojaie, S., Matin, H. Z., \& Barani, G. (2011). Analyzing the infrastructures of organizational silence and ways to get rid of it. Procedia - Social and Behavioral Sciences, 30, 1731-1735. doi:10.1016/j.sbspro.2011.10.334

Spreitzer, G. M. (1995). Psychological empowerment in the workplace: Dimensions, measurement, and validation. Academy of Management Journal, 38(5), 1442-1465.

Sürgevil, O., Tolay, E., \& Topoyan, M. (2013). Yapısal güçlendirme ve psikolojik güçlendirme ölçeklerinin geçerlilik ve güvenirlilik analizleri. Journal of Yasar University, 8(31), 5371-5391. doi:10.1007/s13398-014-0173-7.2

Şan, B. Ç. (2017). Öğretmenlerin ve okul yöneticilerinin psikolojik güçlendirme ve örgütsel bağllllklarına ilişkin algıları (Yayımlanmamış yüksek lisans tezi). Pamukkale Üniversitesi, Denizli.

Tabachnick, B. G., \& Fidell, L. S. (2012). Using multivariate statistics (6th ed.). New York: Harper and Row. doi:10.1037/022267

Taştan, S. B. (2014). The relationship between psychological empowerment and psychological well-being: The role of self-efficacy perception and social support. Öneri Dergisi, 10(40), 139. doi:10.14783/od.v10i40.1012000360

Thomas, K. W., \& Velthouse, B. A. (1990). Cognitive elements of empowerment: An "interpretive" model of intrinsic task motivation. Academy of Management Journal, 15(4), 666-681.

Tolay, E., Sürgevil, O., \& Topoyan, M. (2012). Akademik çalışma ortamında yapısal ve psikolojik güçlendirmenin duygusal bağl1lık ve iş doyumu üzerindeki etkileri. Ege Akademik Bakış, 12(4), 449-465.

Toplu, D., \& Akça, M. (2013). Öğrenen organizasyonun psikolojik güçlendirme üzerindeki etkisi: Kmau sektöründe bir araştırma. İstanbul Ticaret Üniversitesi Sosyal Bilimleri Dergisi Yll, 12(23), 221-235. 
Umar, M., \& Hassan, Z. (2013). Antecedents and outcomes of voice and silence behaviours of employees of tertiary educational institutions in Nigeria. Procedia - Social and Behavioral Sciences, 97, 188-193. doi:10.1016/j.sbspro.2013.10.221

Vakola, M., \& Bouradas, D. (2005). Antecedents and consequences of organisational silence: An empirical investigation. Employee Relations, 27(5), 441-458. doi:10.1108/01425450510611997

Wang, G., \& Lee, P. D. (2009). Psychological empowerment and job satisfaction: An analysis of interactive effects. Group Organization Management, 34(3), 271-96.

Yürür, S., \& Demir, K. (2011). Örgütsel adalet ve psikolojik güçlendşrme: Karş1lıklı etkileri üzerine bir araştırma. Suleyman Demirel University The Journal of Faculty of Economics and Administrative Sciences, 16(3), 311335.

Zimmerman, M. A. (1995). Psychological empowerment: Issue and illustrations. American Journal of Community Psychology, 23(5), 581-599. doi:10.1007/BF02506983 